\title{
The Effect of Learning Methods and Learning Motivation On Indonesian Learning Outcomes Class X Students of Panca Budi Medan High School
}

\author{
Rita \\ Islamic University of Sumatera Utara \\ rita@fkip.uisu.ac.id
}

\begin{abstract}
This study aims to determine the effect of learning methods on Indonesian learning outcomes, the influence of learning motivation on Indonesian learning outcomes and the interaction between learning methods and learning motivation towards learning outcomes in Indonesian. The research method used is the experimental research method, in which a sample of 48 students in class X of Panca Budi Medan High School was selected by cluster random sampling technique, which was previously given a learning motivation questionnaire to determine the learning motivation. Research instruments used to obtain data is a test. Before data collection, the validity and reliability test of the test are carried out. Statistics used in this study are descriptive statistics to test inferential data and statistics for the research hypothesis. The research hypothesis was tested by using two-way ANAVA, which first performed a normality test and homogeneity test for variance. The results of hypothesis testing showed that Indonesian language learning outcomes between groups taught with the module learning method were higher than the group of students taught by direct teacher learning; Indonesian learning outcomes differ between groups of high learning motivated students compared to low motivated learning groups and there is an interaction between learning methods used with student motivation. The results of this study are expected to be input for Indonesian language teachers to apply learning methods or models which are in accordance with student learning motivation or characteristics of students.
\end{abstract}

Keywords : method, motivation, results, learning, language

\section{Introduction}

To improve the quality of education, one component that needs to be observed is the problem of learning strategies that teachers use in the classroom. The low quality of education can be indicated that the quality of learning so far is still less effective, less efficient and less able to increase students' interest and motivation.

One way that can be taken by the teacher in an effort to improve student learning outcomes is to fix the relevant learning methods to achieve learning goals. By using the right learning method and in accordance with the interests or motivations of students learning, the learning outcomes of Indonesian students are expected to be improved or improved. Based on observations, the teacher is dominant with lectures so that students are not creative and less meaningful for him. This observation is done at Panca Budi High School in Medan, especially class X High School (SMA).

Indonesian is one of the subjects tested on national examinations. Thus, efforts need to be made so that students have the competence to listen, speak reading and writing, linguistics and literature. Achieving these competencies is felt necessary to use appropriate methods so that students experience meaningful, creative, innovative, fun and oriented learning. interest or motivation for student learning.

Motivation to learn is a psychological process that occurs in a person due to the interaction between attitudes, needs, decisions and perceptions of someone with the environment. Motivation arises due to factors in a person and factors outside of someone. The 
importances of giving learning motivation for students are departing from the theory of motivational maintenance. Thus, it can be said that there are two factors that increase learning outcomes, namely the method factors used by the teacher in learning and students' learning motivation factors themselves.

From the description above, it can be formulated that the problem to be examined is how are the Indonesian language learning outcomes of Panca Budi High School students in Medan with high learning motivation and low learning motivation and are there interactions between learning methods and the motivation to learn Indonesian? Thus, the results of this study can be used by Indonesian teachers in improving the quality of learning by using learning methods that are relevant to student learning motivation.

\section{Review of Literature}

\subsection{Results of Learning Indonesian}

Gagne (1992) says that researchers show a hierarchical motor (motion) program is not a stimulus-response chain unit but is studied internally. This motor program includes a model of skills and a plan for carrying it out. An internal model such as handwriting or typing is a hierarchical organization of skills that includes all of its skills and sub-skills. Similarly, the plan includes the overall strategy for doing, skills and strategies for sub-skills. When someone starts writing, the movements displayed are guided by a global plan of writing and sub-plans for writing letters and words.

From Gagne's view above, it was revealed that learning is the acquisition of a person's new experience in the form of relatively permanent behavioral changes as a result of a process in the form of learning interactions with an object (knowledge) or through knowledge in the form of an object in a learning environment. There are three characteristics of people who learn an object (knowledge), namely the existence of objects (knowledge), skills, and attitudes that are goals to be controlled; the process of interaction between someone with their environment or learning resources (people, media and others), both through direct experience or learning to participate and the occurrence of new behavioral changes due to learning a certain object (knowledge).

Based on the demands of competency in the curriculum, to master the Indonesian language must be fulfilled the characteristics of the development of students, namely the development of cognitive, psychomotor and affective aspects. an (psychomotor) and attitude (affective) obtained after the students have finished following the learning process that can be seen from changes in behavior that is able to listen, speak, read, write, language and literature.

\subsection{Student Learning Motivation}

Motivation comes from the word motif which means as the strength contained in the individual which is because individuals act or act inkel (1996) says that before referring to the notion of motivation we first examine the identification of words of motives and motivation. Motives are the driving force in a person to carry out certain activities, in order to achieve certain goals. Thus, motivation is an impulse that is contained in a person to try to conduct behavior changes that are better in meeting their needs.

Motivation associated with meaning and cognitive role, is more intrinsic motivation, namely motivation that emerges from within such as interest or curiosity so that someone is no longer motivated by forms of incentives and punishments. While extrinsic motivation is 
motivation caused by the desire to accept ma reward or maybe from punishment. Extrinsic motivation is formed by external factors such as rewards and punishments.

Learning is a process of change of behavior as a result of learning activities or attempts to change behavior, both concerning aspects of knowledge, skills and attitudes .eber in Shah (2011) says that learning is a process of gaining knowledge and a change in the ability to react relatively gears as a result of the exercise done.

Biggs in Syah (2011) said that there are three formulations about learning, namely quantitative formulation, instructional formulation and qualitative formulation. Quantitative learning means the filling or development of cognitive abilities with facts as much as possible. Instructional learning is seen as a process of validation of mastery students for the material he has learned. While qualitatively learning means the process of obtaining meanings and understandings and ways of interpreting the world around students. Thus, learning can be interpreted as a stage of change in individual behavior. relatively settled as a result of experience and interaction with the environment involving cognitive processes. Learning motivation can arise due to intrinsic factors in the form of desires and desires as well as encouragement of learning needs, hopes for ideals. While the extrinsic factors are appreciation, learning environment conducive and learning activities So, it can be conceptually formulated that learning motivation in this research is encouragement to Panca Budi Medan High School students to make behavioral changes in themselves with several indicators or elements that support and play a role in the success of learning. Learning indicators include: curiosity about something, the desire and desire to succeed, the encouragement in learning, learning because of needs, the hope to achieve something, the existence of future ideals, appreciation in learning, interested in learning, utilizing the environment for learning in a conductive manner and accept and work on the tasks given in learning.

\subsection{Learning Methods}

The learning method used in this study is a learning method using modules and learning methods by direct teachers. The learning method uses modules departing from individualoriented individual learning theories and self-development. Individual learning emphasizes personal development namely effort help students to develop productive relationships with their environment and help them to see themselves as capable and useful individuals.

Learning to use or through modules is a way of learning that relates to the delivery of learning materials applied in learning activities. The steps of learning through modules are as follows.

a. Determine topics or material students learn.

b. Assign students to study modules by reading independently.

c. Assign students to pay attention to examples of problems in the module.

d. Assign students to fill in or work on the questions in the module.

e. Ask students to show the results of their work.

f. Instruct students to match the results of their work with the answer key.

g. Give a score on the results of student work for determining whether student connection can move to the next learning module.

Direct teacher learning method is a learning method intended to build a social group that loves each other, appreciates each other, and has discipline and commitment to behave positively. As for the steps of the direct teacher learning method are as follows. 
a. Provide material or topics to be studied.

b. Give apperception to students related to the material that has been learned and introduction to the material to be studied.

c. Convey the goals to be achieved in learning.

d. Explain the material thoroughly to students.

e. Dig questions from students.

f. Give an explanation of the students' questions.

g. Give examples of problems.

h. Give problem exercises.

i. Give a score on the results of student work.

\section{Research Methods}

The method used to carry out this research is the experimental method, with the dependent variable learning outcomes of Indonesian language subjects, the independent variable treatment learning method and the independent variable attribute of student learning motivation. The experimental design applied is factorial, where each variable is independent classified as two levels. Treatment-free variables are classified in the form of learning by learning methods using modules and learning methods through direct teachers. While attribute independent variables are classified in two learning motivations, namely the tendency of high learning motivation and low learning motivation tendency.

The steps taken in carrying out this research are:

1. Disseminate questionnaires about student learning motivation, collect and analyze it.

2. Carry out or do learning by using modules in the high learning motivation class.

3. Carry out or do learning with learning methods the teacher directly on the class of low learning motivation.

4. Give a test about Indonesian language subject matter in both classes.

5. Collect data on test results.

6. Processing and analyzing data.

7. Make research conclusions.

\section{Research Findings and Discussion}

Data on learning outcomes of Indonesian subjects with methods using modules in the following classes. High learning motivation and direct teacher learning methods in the class with low learning motivation can be seen in the following table.

Table 4.1

Description of Data on Indonesian Learning Outcomes

Deskripsi Data Hasil Belajar Bahasa Indonesia

\begin{tabular}{|c|c|c|c|c|}
\hline \multicolumn{2}{|c|}{ Sumber Statistik } & A1 & A2 & $\varepsilon b$ \\
\hline B1 & $\begin{array}{l}\mathrm{N} \\
X \\
S\end{array}$ & $\begin{array}{l}12 \\
32,08 \\
4,85\end{array}$ & $\begin{array}{l}12 \\
33,67 \\
4,75\end{array}$ & $\begin{array}{l}24 \\
32,88 \\
4,77\end{array}$ \\
\hline B2 & $\begin{array}{l}\mathrm{N} \\
\mathrm{X}\end{array}$ & $\begin{array}{l}12 \\
27,33\end{array}$ & $\begin{array}{l}12 \\
17,50\end{array}$ & $\begin{array}{l}24 \\
22,42\end{array}$ \\
\hline
\end{tabular}




\begin{tabular}{|l|l|l|l|l|}
\hline & $\mathrm{S}$ & 4,33 & 3,73 & 6,39 \\
\hline$\varepsilon \mathrm{k}$ & $\mathrm{N}$ & 24 & 24 & 48 \\
& $\mathrm{X}$ & 29,71 & 25,58 & 27,65 \\
& $\mathrm{~S}$ & 5,11 & 9,25 & 7,68 \\
\hline
\end{tabular}

\section{Information :}

A1 $=$ Class $/$ Group of students studying with the module learning method

A2 = Class / Group of students learning by direct teacher learning methods

$\mathrm{B} 1=$ Groups of students have a tendency to high learning motivation

$\mathrm{B} 2=$ Groups of students have a tendency to low learning motivation

$\mathrm{N}=$ Number of samples in each group

$\mathrm{X}=$ Average score on learning outcomes in Indonesian subjects

$\mathrm{S}=$ Standard deviation or standard deviation

The research hypothesis about the differences between the two learning methods can be accepted. This means that the learning method through modules is superior in achieving the learning objectives of Indonesian subjects compared to direct teacher learning methods. The advantages of the learning method through the module are inseparable from the substance of learning theory through modules that emphasize that modules have certain characteristics that distinguish them from other methods.

The research hypothesis about differences in learning outcomes of Indonesian subjects for students with high learning motivation with learning methods through modules and through teachers is immediately rejected. This means that students with high learning motivation, both learning by learning methods through modules and through direct teachers do not show significant differences in Indonesian learning outcomes.

The research hypothesis about the differences in learning outcomes of Indonesian subjects for students who have low learning motivation with learning methods through modules and through teachers is immediately accepted. This means that students who have low learning motivation have different learning outcomes in Indonesian subjects.

\section{Conclusions}

This study found an interaction between learning methods and learning motivation towards the achievement of learning outcomes in Indonesian subjects. Students who have low learning motivation with learning methods through modules achieve higher learning outcomes than with learning methods through direct teachers. For students who have high learning motivation with learning methods through modules or through direct teachers does not show any significant influence. This shows that the effectiveness of a strategy, method or learning model relates to the characteristics of students who are taught or students.

Based on the above conclusions, it is advisable for teachers, especially Indonesian language subject teachers to:

a. Improve the way to teach by learning various methods or models that can improve student learning outcomes or achieve learning goals that have been set.

b. Implement the learning method or model by considering the variable characteristics of students or students. 


\section{References}

Gagne, Robert M.1992. Principles of Instructional Design. New York : Jovanorich College. Robert, C. Beck. 1990. Motivation Theories and Principles. New Yersey : Wake Forest University.

Supardi. 2015. Penilaian Autentik:Pembelajaran Afektif, Kognitif dan Psikomotor. Jakarta: Raja Grafindo Persada.

Syah, Muhibbin. 2011. Psikologi Belajar. Jakarta : Raja Grafindo.

Sujana. 1989. Metode Statistika.Bandung : Tarsito.

Winkel, W. S. 1996. Psikologi Pembelajaran. Jakarta : Grafindo.

Yamin, Martinis. 2012. Strategi Pembelajaran Berbasis Kompetensi. Jakarta : Referensi. 